\title{
The State of İzọn in Bayelsa State Schools
}

\author{
God'spower Tamaraukuro Prezi \\ Niger Delta University, Wilberforce Island, Nigeria
}

\begin{abstract}
In this paper, we look at language and its communicative roles, mother-tongue, İọn, and Ijọ. We observe efforts made by authors to revitalize İọn by writing an orthography, numeracy, metalanguage, and discuss the current state of teaching and learning İọn in Bayelsa State Schools. We look at the similarities and differences between English and İzọn consonants and vowels, and tones in Ịzọn. We note the responsibilities of government, teachers, parents, and students in the revitalization of İọn. We conclude by asking Ịzọns to use their language or lose it; noting the duty of İzọn linguists and literary artists to keep Ịzọn alive by publishing in it; advocating a common orthography for Ijo languages. We recommend to Bayelsa State Government, the immediate compulsory teaching and learning of İzọn, Epie, Nembe, and Ogbia as school subjects in all Universal Basic Education schools in Bayelsa State; the establishment of an İọn Language Academy; the revitalization of Kay Williamson Language Centre, and appointment of a new Director; the establishment of a Bayelsa Readers Project and a Department of Linguistics and Nigerian Languages at Niger Delta University; payment of scholarships, bursaries, and research grants to students of linguistics and İzọn, Epie, Nembe, and Ogbia.
\end{abstract}

Keywords: Bayelsa, İọn, orthography, metalanguage, numeracy

\section{Introduction}

\section{Language}

Language is a set or system of arbitrary, vocal, or other conventionalized linguistic symbols, signs, gestures, or marks which have fixed, understood meanings, which permit all people in a given culture, or other people who have learned the system of that culture, to interact or to communicate (express) ideas (thoughts) or feelings intelligibly with one another.

Language is systematic and generative. It is a set of primarily vocal, but also sometimes visual, arbitrary symbols which have conventionalized meanings and are used by humans for communication in a speech community or culture. Language acquisition or learning by all people has universal characteristics (Wardhaugh \& Brown, 1976, pp. 2-3).

The creative aspect of human language sets it apart from animal languages, which are essentially responses to stimuli.

Language is studied by linguists. Linguistics is the scientific study of language in all its aspects. Linguistics is a scientific discipline whose goal is the construction of a theory of language.

The major communicative roles of language according to Ndimele (2001, pp. 3-5) are: (1) to pass on

God'spower Tamaraukuro Prezi, lecturer, master, Department of English and Literary Studies, Niger Delta University. 
information from one individual to another; (2) to express one's emotions, feelings, or attitudes towards another human being or a state of affairs; (3) as a means of greeting and establishing contact or relationship with other people within one's speech community; (4) to influence other people's behavior or attitudes; (5) to obtain information, ask questions, stimulate actions, issue orders or commands, and make requests, etc.; (6) to control or seek the compliance of nature's forces in accordance with people's beliefs or faith, e.g., in prayers, libation, incantations, divination, and certain rituals; (7) to bring about a change in the state of affairs in the real world as soon as an utterance is made; and (8) for entertaining or amusing people to make them laugh, e.g., dramatic clubs, 'Dẹrịai clubs (Comedy clubs), etc.

According to Bouchard (1998, pp. 19-39), the three fundamental features of the ethnic identity are race, language, and religion. Other features are nationality, sex, class or social group, clan, family and so on. The set of speakers of a language agree on the meaning of words and syntactic structures. Language has the power to name, express, and communicate cultural elements. It promotes social integration and allows the exchange of information essential to human life.

\section{The Concept of Mother-Tongue}

According to Afolayan (1988, p. 1), mother-tongue is the only language of a monolingual person, which meets all his linguistic needs. It is usually the sequential first language of a bilingual or a multilingual person. Ituen $(1998$, p. 1) said mother-tongue is used to refer to the language of one's parents. So, mother-tongue is supposed to be the chronological first language that a child speaks, as he is expected to acquire the language of the mother who is the first person he comes into contact with and communicates with. The mother-tongue is a language in which a person normally has the greatest linguistic ease or intuitive knowledge.

Williamson (as cited in Bamgbose, 1976, pp. 135-153) gave two arguments for using African languages in education. First, the educational argument is the advantage a child has when he learns from as early to as late as possible through the medium of his own language, because he understands it best and it will reduce the break between home and school. Second, the cultural argument is that every person has a right to receive his education and orientation to the modern world through his indigenous language in order not to be culturally deprived. This means that a child's indigenous language "has a contribution to make to the total of human experience and wisdom" (Williamson, as cited in Bamgbose, 1976, pp. 135-153).

\section{Izọn}

İọn means "truth" which is very evident among the İọn people who are very honest, trustworthy, intelligent, brave, and eloquent. The İọn people are the fourth largest ethnic group in Nigeria. They are scattered all over the Niger Delta Region in several states of Nigeria, namely: Bayelsa, Delta, Edo, and Ondo.

İọn is one of the six main languages in Nigeria, the others being Fulfulde, Tiv, Kanuri, Efik, and Edo. The three major languages in Nigeria are Hausa, Igbo, and Yoruba. All the other languages in Nigeria are termed minor languages.

Although Izọn has the largest number of persons who use it as a mother-tongue in Bayelsa State, other indigenous languages exist such as Epie, Nembe, and Ogbia. An orthography, a meta-language, and curricula have been developed for İọn through a partnership between the Federal Ministry of Education, Bayelsa State 
Ministry of Education, NERDC (Nigerian Educational Research and Development Council) and university lecturers including the present writer, as well as Mr. C. B. Agbegha of College of Education, Warri.

İọn, the larger indigenous language in Bayelsa State, will only serve to unify Bayelsans if we also try to recognize the small languages, by using them in the Universal Basic Education programme and later change over to the larger language if necessary.

\section{Ijọ}

Ijaw is the anglicized form of Ijọ which together with its sister language Defaka are Ijoid languages that belong to the Atlantic-Congo branch of the Niger-Congo languages (Williamson, 1989a; Williamson \& Blench, 2000; Donwa-Ifode, 2005). Ijọ is currently spoken in five states in Nigeria: Delta, Edo, Bayelsa, Rivers, and Ondo. Although mutual intelligibility diminishes across dialectal borders, from near to far, yet the people regard themselves as one.

The Ijọ cluster in Nigeria consists of İọn, Nembe, Akassa, and Oruma in Bayelsa State as well as Ibani, Obolo, Kalabarị, Ọkịịka, Bile, and Nkọrọ in Rivers State.

The following are the İzọn clans, which are scattered in Bayelsa, Delta, Edo, and Ondo States: Kolokuma, Opokuma, Gbaraịn, Ekpetiama, Ikibiri, Tarakiri, Bụmọ, Apọi, Basan, Koluama, Fụrụpagha, Olodiama, Oporoma, Oyiakiri, Ogboin, Seimọbiri, Operemọ, Kumbọ, Egbema, Tungbo, Kọ̣, Biseni, Ọkọdịa (in Bayelsa State), Kabụ, Ogbe-Ijọ, Isaba, Iduwini, Ogulagha, Oporoza (Gbaranmatu), Ọbọtebe, Tuomọ, Mein (in Delta State), and Arogbo (in Ondo State), etc.

\section{The Ịọn Language}

\section{Consonants}

The following is a consonant chart showing the 21 consonants in İọn (see Table 1).

Table 1

Izon Consonant Chart

\begin{tabular}{|c|c|c|c|c|c|c|c|}
\hline \multirow{3}{*}{\begin{tabular}{|l} 
Manner of articulation \\
Plosive
\end{tabular}} & \multicolumn{7}{|c|}{ Place of articulation } \\
\hline & Bilabial & \multirow[t]{2}{*}{ Labio-dental } & Alveolar & \multirow[t]{2}{*}{ Palatal } & Velar & Labio-velar & \multirow[t]{2}{*}{ Glottal } \\
\hline & $\mathrm{p}$ & & $\mathrm{d}$ & & g & $\mathrm{kp}$ & \\
\hline Nasal & $\mathrm{m}$ & & $\mathrm{n}$ & & $y$ & & \\
\hline Fricative & & $\mathrm{f}$ & $\mathrm{z}$ & & 8 & & $\mathrm{~h}$ \\
\hline Trill & & & $\mathrm{r}$ & & & & \\
\hline Lateral & & & 1 & & & & \\
\hline Approximant & & & & $\mathrm{j}$ & & w & \\
\hline
\end{tabular}

Notes. The phonemes on the left hand side of the boxes are voiceless while those on the right hand side are voiced; see section "The consonants of İọn" below and C. B. Agbegha, G. T. Prezi, Tarilayefa, and A. Prezi (2011, pp. 2-3) for details on Ịzọn consonants.

\section{Vowels}

Figure 1 is a chart showing the nine oral vowels of İọn.

The İọn language is made of nine vowels and 21 consonants. There are nine oral vowels in İọn. The first set of vowels: $\mathbf{i}, \mathbf{e}, \mathbf{0}$, and $\mathbf{u}$ are wide while the second set $\mathbf{i}, \mathbf{e}, \mathbf{0}$, and $\mathbf{u}$ are narrow. The wide vowels and the narrow vowels do not occur together in a simple word. There is vowel harmony of the eight non-open vowels. The open vowel /a/ is neutral to vowel harmony. It co-occurs with either set (see Example (1)). 


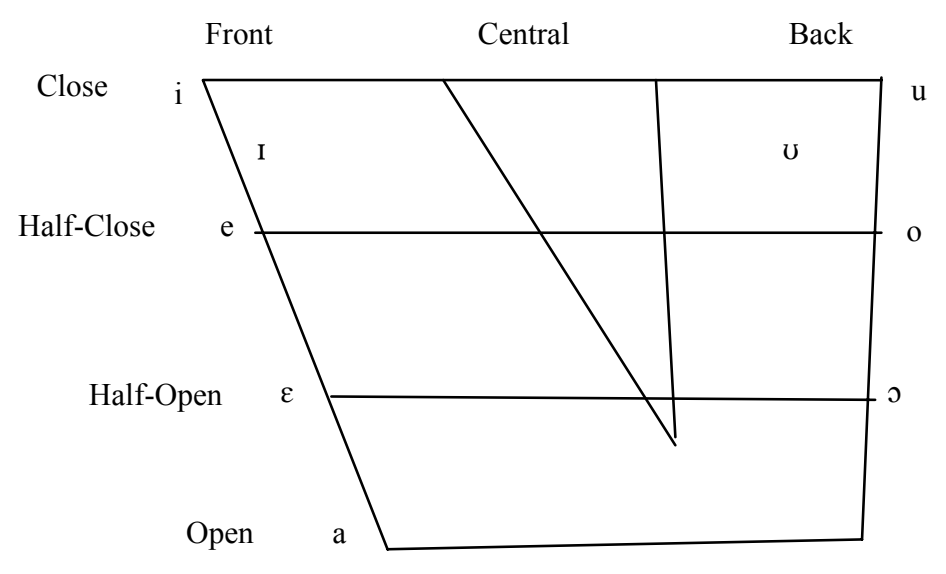

Figure 1. İọn vowel chart.

Note. All the front vowels are unrounded, while all the back vowels are rounded.

Example (1) Oral vowels: a e i o u (wide vowels) /e, i, o, u/

$$
\text { ẹ ị ọ ụ (narrow vowels), i.e., /ع, I, o, v/ }
$$

When two vowels occur in a word before a final $\mathbf{n}$, both are affected by the nasalization (see Example (2)):

Example (2) kaịn "to be torn" kịen "to count" gbẹ̣n "to throw, to sew"

See "Oral vowels" and "Nasalised vowels" in section "The vowels of İọn" below and G. T. Prezi (2014, pp. 37-38) for more details on Ịzọn vowels.

\section{İọn Language as a Means of Communication, Identity, and Cultural Instrument}

Izọn language is a means of communication among persons in the Izọn speech community. It is among the first things a child learns in Ịzọnland to enable him/her to acquire or learn various useful skills such as fishing, farming, canoe-carving, trading, building of mud/thatch houses, story-telling (at moonlight in the evenings when real-life stories and fiction are told for the education of the young and old), and any other art or cultural activities from their parents or guardians and elders in society. The İọn language is therefore important in the development of an İọ̣n person and the Ịzọn society.

The İộn language serves as an identity to the İọn people. Language helps one to promote his/her dignity and personality. The İọn man always talks with confidence and dignity. The İọn language and culture of the people is transmitted to the child through a gradual socialization process. Children usually grow up to speak the language of their parents and the environment to which they are exposed. We can invent or borrow or coin a word or the name of a particular object with the aid of language.

The İọn language is a primary element of İọn culture. Language serves as the means through which all the other elements of culture can be made known to everybody. The relevance of language to humans is that it is the vehicle of thought, self-expression, and the keeping of records. It is central in determining social thought. Language determines what people think and influences people's perception.

\section{The State of İzọn in Bayelsa Schools}

\section{The Teaching of İzọn in Bayelsa Schools}

İọn is taught in a few government-owned and private primary and secondary schools in Bayelsa 
State among which are Ayakpo Group of Schools in Biogbolo, Benny's International Nursery, Primary and Secondary Schools at Akenpai, Faith Comprehensive Secondary School, Okutukutu, and Tare Pet Schools in Kpansia.

\section{The CNDS (Centre for Niger Delta Studies), Niger Delta University}

CNDS, Niger Delta University, Wilberforce Island, Bayelsa State where the author also teaches, started the Diploma in Izọn Language Programme with about 60 pioneer students in the 2008/2009 academic session with professor Okaba as Director. It is part of the Centre's contributions to the successful implementation of the National Language Policy on the use of mother-tongue as medium of instruction at the Universal Basic Education levels and the resuscitation of our highly endangered linguistic and cultural heritage. We had two options then: Mother Tongue Education option with about 40 students made up of serving and interested language teachers in Primary and Secondary Schools in Bayelsa State, and Proficiency Training option with about 20 students consisting of persons seeking proficiency in speaking and writing in İzọn.

The foundation set of students graduated in the year 2012. Among them are Mr. Victor Abite who teaches İọn in the Junior Section at Faith Comprehensive Secondary School, Okutukutu; Chief Fresh T. Omonibou and Mr. Rimo Igbeinkutu who teach Ịzọn at Ayakpo Group of Schools in Biogbolo, Yenagoa; Ineidide Yakegba who broadcasts in İọn at Nigerian Television Authority, Yenagoa; Chief Peter Nwankwe and P. Zidougha who work at the CNDS and teach in the Diploma in İọn Language Programme of the CNDS; and Mr. Tamuno Odonbilo Kikiriki, a Headmaster and İọn teacher in a primary school in Kolokuma/Opokuma LGA, who also teaches in the Diploma in İọn Language Programme of the CNDS.

A new set of about 110 students commenced the Diploma in İọn Language Programme last year under the new Acting Director, Dr. Ibaba S. Ibaba. The programme consists of three contact periods and the following Izọn Language and Linguistics courses are taught: Listening and Speaking Skills in Ịzọn, Standard Spelling in Ịzọn, Advanced Reading and Writing Skills in İzọn, Introduction to Language, English Language and Communication, Introduction to Ịzọn Orthography, The Use of Ịzọn, Comprehension and Composition in Ịzọn, İzọn Phonetics and Phonology, Morphology and Syntax of Ịzọn, Introduction to Cultural Studies of İzọn People, Introduction to İzọn Oral Literature, Principles of Translation in İzọn, Introduction to Linguistics, Written Izọn Literature, Comprehension and Summary Writing in İzọn, Composition Writing in Ịzọn, İọn Language Development, and Introduction to İọn Language in Contact.

The İọ̣n Language Diploma Programme also covers various aspects of Ịzọn History, Oral Literature, Culture, İọn Mathematics, Science, and Introductory Technology.

Apart from the author's humble self, lecturers currently teaching in the Izọn Language Diploma Programme are professor Wenikado Ganagana, Dr. Sunday D. Abraye, Dr. O. M. Kwokwo, Bertola Perekeme, E. C. Eneware, Engineer Sapre-Obi, Chief Nwankwe Peter, Patrick Zidougha, Elliot Sibiri, Rachael Ase, Yengizifa Clarkson, O. K. Tamuno, and W. Worufah.

\section{Revitalizing !zọn Language for the 21st Century}

In order to revitalize the Izọn language, as well as place the İzọn language in a position of envy, certain responsibilities must be placed on government, certain organizations and bodies, as well as on individuals. 


\section{Numeracy}

Linguists can come to the aid of publishing by helping in the development of numeracy in Izọn. Williamson, Timitimi, Egberipou, Vianana, and Odogu (1990, pp. 49-93) had produced a vocabulary of primary science and Mathematics for İọn. The present writer also wrote a detailed academic paper on the Numeral System of İọn (G. T. Prezi, 2013, pp. 245-257).

\section{Metalanguage}

Linguists can also come to the assistance of publishing by helping in the development of a metalanguage for Izon. Metalanguage is one of the larger issues of lexical expansion. Metalanguage is specialized language for different registers. Every language has to expand its vocabulary if it must meet up with current issues and be used in publishing in modern times. Linguists can perform this task of metalanguage development through appropriate transliteration, translation, borrowing, and so on for İọn and other undeveloped indigenous languages. However, we are again lucky that late Dr. Efere, C. B. Agbegha, and the present author developed a metalanguage for İọn for the NERDC with UNESCO (United Nations Educational, Scientific, and Cultural Organization) sponsorship in 2007 (C. B. Agbegha, Efere, \& G. T. Prezi, 2007).

\section{Responsibility of the Government}

This author recalls that the Bayelsa State Commissioner for Culture and Ijaw National Affairs, Dr. Felix Tuodolo attended the flag-off ceremony of the new Diploma Programme in İọn Language at Benny's International School at Akenpai in Yenagoa in 2012.

The Bayelsa State Government under Governor Henry Seriake Dickson in 2013 awarded a scholarship to 110 students doing a Diploma Programme in Ịọ̣n Language at the CNDS at Niger Delta University, Wilberforce Island, Bayelsa State. However, the Bayelsa State Government needs to sustain this effort by consistently awarding this scholarship to serving teachers in the Universal Basic Education system and the Post-Primary School system and other deserving students over the next three to five years to enable the State to have at least an average of one trained İọn teacher to one primary or secondary school. The State Government should also encourage and sponsor İọn language teachers and linguists to cooperate and write books. Books on İọn language and literature should be printed and published free of charge by the State printing and publishing corporation. The Bayelsa State Government and its subsidiary local governments must undertake serious language planning in the manner suggested below, with the collaboration of the LAN (Linguistic Association of Nigeria) whose current president is professor Chinyere Ohiri-Aniche, and its local branch, the LABS (Linguistic Association of Bayelsa State). The linguists, who are experts, will undertake the language planning through the stages of: fact finding, selection, development, implementation, feedback and evaluation; or selection, codification, elaboration, implementation, and acceptance.

Language planning is concerned with sustained conscious efforts in the pursuit of long-term solutions to problems which involve the functional use of our indigenous languages (especially Izonn in Bayelsa State) for the purpose of solving communication problems, standardization, bilingualism, and multilingualism.

Status planning involving the planning of changes in the standing of İọn vis-a-vis English and other indigenous languages in our Primary and Junior Secondary Schools (i.e., in the UBE (Universal Basic Education) System) should be undertaken by the State Government. 
Corpus planning primarily involves changes in the language code, i.e., changes in the structure, vocabulary, dictionaries, literature books, the system of spelling (orthography), and script.

It is important to note that the factors responsible for success in language learning by students are the soundness of teaching methods, the attitudes and motivation of the learner, the availability of time and opportunities to learn, the adequacy of resources, and the chance to put the language to use (Crystal, 1997, p. 368).

Again, according to Lightbown and Spada (1993, p. 116), language learning is affected by many factors among which are the personal characteristics of the language learner, the structure of the language involved, opportunities for interaction with speakers of the language, and access to correction by teachers and form-focused instruction and teaching.

\section{Responsibility of the School}

The school time-table planners should increase the time allocated to İọn in Bayelsa, Delta, Ondo, Edo States in Nigeria, as well as to Nembe, Ogbia, and Epie in Bayelsa State. The various schools should ensure that there is enough time on the class and general school time-table for the teaching of İọn, in Bayelsa, Delta, Ondo, Edo, and other İzọn and Ijọ speaking states in Nigeria, as well as to Nembe, Ogbia, and Epie in Bayelsa State. We recommend teaching these languages at least for two lesson periods of 40 minutes each, at least three days a week.

\section{Responsibility of the İọn Teachers}

Design of pedagogical materials. Izọn teachers should use pedagogical materials such as minimal pairs and flash cards (word cards and sentence cards) for teaching the language.

Teaching methods. To become proficient in the mother-tongue, the learner must be given opportunities to use it for communicative purposes. Teachers should stress student's involvement in life-like conversations. We suggest audio-lingual teaching practices where much class time should be devoted to the development of listening and reading abilities as well as speaking practice. Teachers should also assess student interests and supply appropriate materials for learning.

Efforts should be made to systematically measure or evaluate the effectiveness of language teaching practices in promoting Izọn language acquisition and learning by natives and non-natives schooling in the Bayelsa State Educational System.

Izọn language teachers should do a CA (Contrastive Analysis, a systematic descriptive analysis and comparison of specific linguistic characteristics) of English and İọn. CA brings out the differences between the two languages which are expected to pose problems to learners and therefore permits the teacher to devise lots of exercises on the potentially problematic points of difference for the learners. It also brings out the similarities between the two languages which would facilitate learning. Whitman's (1970, p. 191) CA proceeds through four steps: description, selection, contrast, and prediction.

CA of Izọn and English. The following is a phonological CA of Izọn and English consonants and vowels.

The consonants of English. There are 24 consonants in English: /p, b, t, d, k, g, f, v, $\theta$, , , s, z, J, 3, tf, dz, l, $\mathrm{r}, \mathrm{j}, \mathrm{w}, \mathrm{h}, \mathrm{m}, \mathrm{n}, \mathrm{y} /$.

The consonants of Izon. There are 21 phonemic consonants in the Tarakiri dialect of Izọn spoken in Isampọụ. İọ̣n has no consonant clusters (see Table 2). 
Table 2

The Consonants of Izon

\begin{tabular}{|c|c|c|c|c|}
\hline No. & Orthography & Phoneme & Example in Ịzọn & English gloss \\
\hline 1 & $\mathrm{p}$ & $/ \mathrm{p} /$ & $\begin{array}{l}\text { pa } \\
\text { pịiṇ }\end{array}$ & $\begin{array}{l}\text { "appear" } \\
\text { "to give" }\end{array}$ \\
\hline 2 & $\mathrm{~b}$ & $/ \mathrm{b} /$ & ba & "to kill" \\
\hline 3 & $\mathrm{t}$ & $/ \mathrm{t} /$ & $\begin{array}{l}\text { tịn (verb; noun) } \\
\text { tụbọụ }\end{array}$ & $\begin{array}{l}\text { "to call"; tree } \\
\text { "child" }\end{array}$ \\
\hline 4 & d & $/ \mathrm{d} /$ & $\begin{array}{l}\text { dadi } \\
\text { dawai }\end{array}$ & \begin{tabular}{|l|} 
"father" \\
"to dream"
\end{tabular} \\
\hline 5 & $\mathrm{k}$ & $/ \mathrm{k} /$ & $\begin{array}{l}\text { ka } \\
\text { koro }\end{array}$ & $\begin{array}{l}\text { "be mature" } \\
\text { "to fall; alight" }\end{array}$ \\
\hline 6 & $\mathrm{~g}$ & $/ \mathrm{g} /$ & \begin{tabular}{|l|} 
ga \\
goo
\end{tabular} & $\begin{array}{l}\text { "worship" } \\
\text { "to read" }\end{array}$ \\
\hline 7 & f & $/ \mathbf{f} /$ & $\begin{array}{l}\text { fa } \\
\text { fịrị } \\
\end{array}$ & $\begin{array}{l}\text { "be lost" } \\
\text { "work" }\end{array}$ \\
\hline 8 & $\mathrm{~V}$ & $/ \mathrm{v} /$ & $\begin{array}{l}\text { vumuye } \\
\text { vinmọ }\end{array}$ & $\begin{array}{l}\text { "catapult" } \\
\text { "to quench" }\end{array}$ \\
\hline 9 & $\mathrm{~s}$ & $/ \mathrm{s} /$ & \begin{tabular}{|l|} 
sara \\
sango
\end{tabular} & $\begin{array}{l}\text { "funnel" } \\
\text { "demijohn (glass jar)" }\end{array}$ \\
\hline 10 & $z$ & $|z|$ & $\begin{array}{l}\text { zuye } \\
\text { zii }\end{array}$ & $\begin{array}{l}\text { "type of fish trap" } \\
\text { "to give birth" }\end{array}$ \\
\hline 11 & 1 & $/ 1 /$ & $\begin{array}{l}\text { la (verb) } \\
\text { lọo }\end{array}$ & $\begin{array}{l}\text { "to reach" } \\
\text { "to massage" }\end{array}$ \\
\hline 12 & w & $/ \mathrm{w} /$ & $\begin{array}{l}\text { warị } \\
\text { weri } \\
\end{array}$ & $\begin{array}{l}\text { "house" } \\
\text { "to abuse" }\end{array}$ \\
\hline 13 & $\mathrm{r}$ & $/ \mathrm{r} /$ & \begin{tabular}{|l|} 
raga \\
ariri
\end{tabular} & $\begin{array}{l}\text { "fish trap" } \\
\text { "fishing net" }\end{array}$ \\
\hline 14 & $\mathrm{~h}$ & $/ \mathrm{h} /$ & haan & "rallying cry" \\
\hline 15 & $\mathrm{y}$ & $/ \mathrm{j} /$ & $\begin{array}{l}\text { yọwẹi } \\
\text { yiin }\end{array}$ & $\begin{array}{l}\text { "paddle" } \\
\text { "mother" }\end{array}$ \\
\hline 16 & $\mathrm{~m}$ & $/ \mathrm{m} /$ & $\begin{array}{l}\text { mọ } \\
\text { mọun }\end{array}$ & $\begin{array}{l}\begin{array}{l}\text { (conj) "and" } \\
\text { "hunger" }\end{array} \\
\end{array}$ \\
\hline 17 & $n$ & $/ \mathrm{n} /$ & \begin{tabular}{|l} 
nana \\
nini
\end{tabular} & $\begin{array}{l}\text { “possess” } \\
\text { "nose" }\end{array}$ \\
\hline 18 & ng & $/ \mathrm{y} /$ & angi & “"egg” \\
\hline 19 & $\mathrm{kp}$ & $/ \mathrm{p} /$ & akpa & "bag" \\
\hline 20 & $\mathrm{gb}$ & $/ \mathrm{gb} /$ & \begin{tabular}{|l|} 
gbabụ \\
gboro
\end{tabular} & $\begin{array}{l}\text { "be narrow" } \\
\text { "to plant" }\end{array}$ \\
\hline 21 & gh & $/ \mathrm{y} /$ & $\begin{array}{l}\text { gha } \\
\text { bogha }\end{array}$ & $\begin{array}{l}\text { "not" } \\
\text { "did not come" }\end{array}$ \\
\hline
\end{tabular}

The vowels of English. There are 23 vowels and diphthongs in English: /i:, i, I, ع, æ, a:, p, o:, u, u, u:, $\Lambda$, 3:,

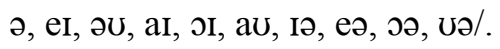

The vowels of Izon. Oral vowels. There are nine phonemic oral vowels in Izon. There is vowel harmony of the eight non-low vowels. The low vowel /a/ is neutral to vowel harmony. It co-occurs with either set. The first set of vowels: $\mathbf{i}, \mathbf{e}, \mathbf{o}$, and $\mathbf{u}$ are wide while the second set $\mathbf{i}, \mathbf{e}, \mathbf{0}$, and $\mathbf{u}$ are narrow. The wide vowels and the narrow do not normally go together in a simple word, as can be observed in Table 3 (G. T. Prezi, 2014, p. 37).

Nasalised vowels. There are nine nasalized vowels in İọn. They are: ã, ẽ, $\tilde{\varepsilon}, \tilde{1}, \tilde{\mathrm{I}}, \tilde{\mathrm{o}}, \tilde{\mathrm{o}}$, ũ, and $\tilde{u}$. When a vowel occurs in a nasal environment, the vowel becomes nasalized. When two vowels occur in a word before the final $\mathbf{n}$, both are affected by the nasalization. Usually, in the orthography, as shown in these examples, kain "be 
torn"; kién "to count"; and gbein "to throw", "to sew", nasalization in a word is shown by writing the consonant "n" at the end of the syllable after the vowel as illustrated in Table 4 (G. T. Prezi, 2014, p. 37).

Table 3

Oral Vowels: a e i o u e i

\begin{tabular}{|c|c|c|c|c|}
\hline No. & Orthography & Phoneme & Examples in Ịzọn & English gloss \\
\hline 1 & $\mathrm{a}$ & $/ \mathrm{a} /$ & $\begin{array}{l}\text { aba } \\
\text { aka } \\
\text { ada }\end{array}$ & $\begin{array}{l}\text { "type of fish" } \\
\text { "tooth, maize" } \\
\text { "paint" }\end{array}$ \\
\hline 2 & e & /e/ & $\begin{array}{l}\text { ele } \\
\text { epele }\end{array}$ & $\begin{array}{l}\text { "gorilla" } \\
\text { "draught" }\end{array}$ \\
\hline 3 & $\mathrm{i}$ & /i/ & $\begin{array}{l}\text { diri } \\
\text { bii } \\
\text { di } \\
\end{array}$ & $\begin{array}{l}\text { "medicine" } \\
\text { "to ask" } \\
\text { "to look" }\end{array}$ \\
\hline 4 & o & $/ \mathrm{o} /$ & $\begin{array}{l}\text { obori } \\
\text { ofoni } \\
\text { koro }\end{array}$ & $\begin{array}{l}\text { "goat" } \\
\text { "bird, fowl" } \\
\text { "to fall" }\end{array}$ \\
\hline 5 & $\mathrm{u}$ & $/ \mathrm{u} /$ & $\begin{array}{l}\text { oku } \\
\text { furu }\end{array}$ & $\begin{array}{l}\text { "be heavy" } \\
\text { "to steal" }\end{array}$ \\
\hline 6 & ẹ & $/ \varepsilon /$ & $\begin{array}{l}\text { fẹrẹ } \\
\text { pẹlẹ } \\
\text { pẹrẹ }\end{array}$ & $\begin{array}{l}\text { "enamel" } \\
\text { "to cut, to stop" } \\
\text { "king, be rich" }\end{array}$ \\
\hline 7 & $\mathrm{i}$ & $/ \mathrm{I} /$ & $\begin{array}{l}\text { fị } \\
\text { fịị } \\
\text { dị }\end{array}$ & $\begin{array}{l}\text { "to eat, to die" } \\
\text { "work" } \\
\text { "skill" }\end{array}$ \\
\hline 8 & o & $/ / 2 /$ & \begin{tabular}{|l|} 
kọrọ \\
tọlọ
\end{tabular} & $\begin{array}{l}\text { "raphia palm" } \\
\text { "to pick up an object" }\end{array}$ \\
\hline 9 & ụ & $/ \mathrm{U} /$ & $\begin{array}{l}\text { arụ } \\
\text { bụ }\end{array}$ & $\begin{array}{l}\text { "canoe" } \\
\text { "pond" }\end{array}$ \\
\hline
\end{tabular}

Table 4

Izon Distinguishes Between Oral Vowels and Nasalized Vowels

\begin{tabular}{|c|c|c|c|c|}
\hline No. & Orthography & Phoneme & Examples in İọn & English gloss \\
\hline 1 & ã & ã & $\begin{array}{l}\text { kan } \\
\tan \end{array}$ & $\begin{array}{l}\text { "to wander"; to tear } \\
\text { "to pack, gather" }\end{array}$ \\
\hline 2 & $\tilde{\mathrm{e}}$ & $\tilde{\mathrm{e}}$ & geen & "be brightly-lit" \\
\hline 3 & ẹ & $\tilde{\varepsilon}$ & sẹện & "to shave" \\
\hline 4 & $\tilde{1}$ & ĩ & piin & "be crowded" \\
\hline 5 & $\tilde{i}$ & $\tilde{\mathbf{I}}$ & \begin{tabular}{|l|} 
pịn \\
adẹin
\end{tabular} & $\begin{array}{l}\text { "to tap as in palm wine" } \\
\text { "knife" }\end{array}$ \\
\hline 6 & $\tilde{\mathrm{o}}$ & õ & goon & "be extra bright, of light" \\
\hline 7 & $\tilde{o}$ & $\tilde{\mathrm{o}}$ & tọn & "to measure" \\
\hline 8 & $\tilde{\mathrm{u}}$ & $\tilde{\mathrm{u}}$ & tũn & "cap; hat" \\
\hline 9 & $\tilde{u}$ & $\tilde{U}$ & $\begin{array}{l}\text { sụn } \\
\text { mọun }\end{array}$ & $\begin{array}{l}\text { "to stretch" } \\
\text { "hunger" }\end{array}$ \\
\hline
\end{tabular}

Note. see G. T. Prezi (2014, p. 37) and C. B. Agbegha et al. (2011, p. 3).

The tonal system of Izon. Izọn is a tone language like most Nigerian languages. That is to say, it is a syllable-timed language, while English is a stress-timed language.

Tone, according to Williamson (1989a), is the pitch of the voice that makes a difference in the meaning of the words which have the same segmental phonemes. Generally, İọn has only two tones: high (marked with ') and low which is usually left unmarked. 
(1) Low Tone: ado

"Edo/Bini"

agbada

abo

(2) High Tone: adó

abá

abó

"bridge", "raised platform", or "one of the ribs"

"a kind of bag woven from raffia or leaves of screwpine"

"basket"

"a kind of fresh water fish (Gymnarchus niloticus)"

"canal"

Phonological similarities. Consonants. /p, b, t, d, k, g, f, v, s, z, l, r, j, w, h, m, n, y/ are present in both the L1 and the Target Language systems. İọn speakers therefore have no problem with English nasals.

Vowels. /a, e, e, i, I, o, o, u, $\mathrm{U} /$ feature in both languages.

Phonological differences. Consonants. A CA of English and İzọn shows that certain consonants $/ \int, \mathrm{t} f, \theta$, $\partial$, 3, d3/ which occur in English do not occur in Ịzọn, while certain consonants like /gb, gh, kp/ which occur in İzọn do not occur in English.

Thus when a native speaker of İọn wants to pronounce English words containing the above-mentioned six consonants, he/she is likely to substitute İzọn consonants which are closest to the English ones. Thus he may substitute: (1) İzọn /s/ for English / / / and /t $\mathrm{f} /$ in words like "fish" which they pronounce "fis" and "church" which they pronounce "surs"; (2) Ịzọn /t/ for English / $\theta$ / in words like "tink" for "think"; (3) İzọn /d/ for English /ð/ in words like "dat" for "that"; and (4) İzọn /z/ for English /3/ and /dz/ in words like "beiz" for "beige" and "zuz" for "judge".

Vowels. Also, four English pure vowels /æ, $\Lambda, 3:$, ə/ and five English diphthongs /ə৩, เə, еə, ๖ə, ৩ə/ do not occur in İọn, and as such are likely to constitute a problem to Ịzọn speaking learners of English who are likely to substitute: (1) Ịzọn /a/ for English /æ/ and /a/ in words like "bad" and "about" respectively; (2) İọn /o/ for English / $/$ in words like “cut”, "but”, etc.; (3) İzọn /ou/ for English /ov/ in words like "boat”, "coat”, etc.; and (4) İzọn /E/ for English /3:/ in words like "bird" and "girl".

İọn has no diphthong, but two vowels can come together in a sequence to produce sounds similar to the English diphthongs /eI, aI, oI, au/.

\section{Responsibility of the Parents}

Parents are to ensure that they buy the available İọn textbooks, ensure that their children and wards do their İọn assignments, as well as assist them when necessary.

\section{Responsibility of the Students}

The only responsibility of the students is to take their İọn language studies seriously and do the exercises and assignments given to them by their teachers, diligently.

\section{Conclusions}

First, in a lecture titled "A Common Language for the Ijaw Ethnic Nationality" which late professor Kay Williamson delivered on 1st May, 2003 at a meeting of the INC (Ijaw National Congress), she concluded by telling the Ijaw elders and stakeholders to use their language or lose it. Although İọn, Epie, Nembe, and Ogbia are being used for radio and television broadcast, and have been accepted for use in schools, the actual implementation of the use of these languages in the teaching-learning process on a large scale is yet to commence 
in Bayelsa State and other İọ̣n-speaking States. As we noted in section "The Teaching of İộn in Bayelsa Schools" above, İọn is taught only in a few government-owned and private primary and secondary schools in Bayelsa State among which are Ayakpo Group of Schools in Biogbolo, Benny's International Nursery, Primary and Secondary Schools at Akenpai, Faith Comprehensive Secondary School, Okutukutu, and Tare Pet Schools in Kpansia. This is definitely far from being enough.

Second, the future of a language depends on how the native speakers regard their language. It is the duty of İọn linguists and literary artists to keep their mother-tongue alive by publishing in the language. According to Emenanjo (1986), for any sort of writing to exist in any language, there must be an accepted orthography, a standard variety of the language (late professor Kay Williamson adopted Kolokuma), a metalanguage (C. B. Agbegha et al., 2007), authors, computers with the appropriate characters and diacritics employed in the language (use KONYIN keyboard), modern printers with the right matrices, and fonts for the language (use SIL Doulos Ipa93dc to sr fonts). Linguists can aid publishing through the popularization of Izon, and the development of an accepted orthography (C. B. Agbegha et al., 2011), a dictionary (Williamson \& Timitimi, 1983; M. L. Agbegha, 1999, etc.), a modern numeral system (G. T. Prezi, 2013), as well as texts such as primers, grammars, educational books, and cultural materials; lexical expansion, lexical innovation, and new frames of discourse for the İọ̣ language.

Third, Williamson (2003) concluded that: "It is not practicable to identify one common language for the Ijaw Ethnic Nationality" but "we can try as much as possible to develop a common orthography which can be used for all languages" (p. 8). The author is happy to say that in 2011, he worked with Mr. C. B. Agbegha of College of Education Warri to produce A Unified Standard Orthography for the Ijo Language Cluster (Nigeria) (2011) published in Cape Town, South Africa. It was approved by the Federal Ministry of Culture and then handed over to the Federal Ministry of Education in 2012 to be used in schools and colleges for all the Ijaw (Ijọ) languages.

\section{Recommendations}

In order for us to successfully resuscitate and develop the Izọn language and culture, and in order to re-position the İọn language and culture for use in the 21 st century, the author hereby recommends the following.

First, the author recommends the immediate urgent and compulsory implementation of the teaching of Izon as a school subject, and the use of Izọn, Epie, Nembe, and Ogbia for teaching and learning purposes as the mother-tongue of the immediate environment in our UBE system, that is, from Primary One to JSS 3 in all public and private schools in Bayelsa State.

Second, the author recommends the establishment of an İọn language newspaper by the Bayelsa State Government under the Bayelsa Printing and Publishing Press and Newspaper Corporation, under the aegis of the State Ministry of Information.

Third, an Izọn Language/Linguistic Academy much like the French Academy or the one proposed by Jonathan Swift for English should be established in Yenagoa, the State capital. This should be made up of professional linguists and language teachers at Niger Delta University, Wilberforce Island, and the Isaac 
Jasper Adaka Boro College of Education. Together with some State Government officials, these professionals should form the core of the persons to carry out the language planning activities which include status planning and corpus planning.

Fourth, the Bayelsa State Government should appoint a new Director for and make functional the Kay Williamson Language Centre, Kaiama to provide the much-needed technical expertise and coordination. It was not functional during the tenure of the late Dr. Efere, and has died a natural death since his demise. A series of İọn, Epie, Nembe and Ogbia languages, linguistics and training Workshops, Conferences, Symposia and Seminars should be held regularly by the Kay Williamson Language Centre, Kaiama in and on these languages for teachers of indigenous Bayelsa State languages at all levels of Education. The Niger Delta University Inter-disciplinary Studies Committee should work with the Kay Williamson Language Centre when it is revived, and collaborate with the Department of English and Literary Studies at NDU (Niger Delta University), the Faculty of Science at NDU, and the Department of Linguistics and Communication Studies of the University of Port Harcourt for the development of scientific and technical terminology such as square, cylinder, etc., in İzọn.

Fifth, there is the need to establish a Bayelsa Readers Project to replace the moribund Rivers Readers Project. Bayelsa State and Local Governments, through its Ministry of Education, its UBE Board and its Local Government Education Authorities need to finance the training and retraining of teachers on how to use the language materials that were produced by the Rivers Readers Project. Thus, they can do in conjunction with the Language Unit of the Department of English and the Faculty of Education at NDU as well as the Kay Williamson Language Centre. Bayelsan and other İọn (and Ijọ) linguists and scholars should be encouraged by the State and Local Governments to write or co-author and publish textbooks, documents and articles in language, literature and other school subjects such as religion for use in Bayelsa schools and colleges. In addition, there is also the need to rejuvenate, revise and re-edit the readers and other materials published by the Rivers Readers Project, to make them suitable for current use in our primary and secondary schools in Bayelsa State. Specifically, to attract more readers in İọn language, authors and publishers have to diversify from publishing only primers, grammars and course books and go into interesting literary publication of folk tales, fables, and children story books.

Sixth, more linguists who are proficient in Izọn and other Bayelsa languages should be employed in the Department of English and Literary Studies at Niger Delta University, and later a full-fledged Department of Linguistics, Nigerian Languages and Communication should be established.

Seventh, undergraduate and post-graduate scholarships, bursaries and research grants should be paid to students of Linguistics in general and especially Izọn, Epie, Nembe, and Ogbia by the Bayelsa State Government, much like what is being paid to some science students by the Petroleum Trust Fund.

Eighth, as Bayelsa State Government has declared that we wear our traditional İọn, Epie, Nembe and Ogbia cultural attires to work on Fridays, in a similar vein Government should make it mandatory for all its workers in the State to greet in and speak as much as they can of their mother-tongue on Fridays.

Ninth, we should key into the recommendations made by Okaba (2008, pp. 18-21) concerning the way forward for developing Ịzọn, viz: (1) İzọn and Ijọ cultural conferences, gatherings, and meetings should be 
conducted in İzọn; (2) A standard Ijọ dictionary should be produced with dialectal cross-referencing; (3) A standard Ijọ language should be developed for use as the medium of communication in the media, as well as for answering questions in the West African Examinations Council Examinations; and (4) The Bayelsa State Ministry of Culture and Ijaw National Affairs should organize an annual Cultural Festival or Fiesta in which there would be cultural displays, quizzes, recitations, drama, essay, and other competitions in İọn and Ijọ language and culture.

\section{References}

Afolayan, A. (1988). The new language policy and effective instruction in schools. Language in Education in Nigeria, $1,1$.

Agbegha, C. B., Efere, E. E., \& Prezi, G. T. (2007). Izon metalanguage. Abuja: NERDC.

Agbegha, C. B., Prezi, G. T., \& Perekeme, B. (2010). Federal Ministry of Education: 9-year basic education curriculum. Izon Language for Primary 1-3 and for Primary 4-6. Abuja: NERDC.

Agbegha, C. B., Prezi, G. T., Tarilayefa, K., \& Prezi, A. (2011). A unified standard orthography for the Ijo language cluster (NIGERIA). Cape Town: Centre for Advanced Studies of African Societies.

Agbegha, M. L. (1999). Izon-English dictionary (Mein dialect). Port Harcourt: Riverside Communications.

Bamgbose, A. (Ed.). (1976). Mother tongue education: The West African experience (pp. 135-153). London: Hodder and Stoughton; Paris: UNESCO Press.

Bouchard, C. (1998). La langue et le nombril (Language and the navel) (pp. 19-39). Québec: Nouvelles Etudes Québécoises.

Crystal, D. (1997). Cambridge encyclopedia of language (2nd ed.). Cambridge: Cambridge University Press.

Donwa-Ifode, S. (2005). Preliminary historical inferences from Ijọ Loan Words in Delta-Edoid Languages. In E. N. Emenanjọ, \& O.-M. Ndimele (Eds.), Essays in honour of Kay Williamson. Aba: Central Books, Nigeria.

Emenanjọ, E. N. (1986). Academic publishing in Nigerian languages. An unpublished paper given to the University of Port Harcourt Press.

Fishman, J. (1974). Language planning and policy: Recent trends, future directions. The Hague: Mouton.

Ituen, S. A. U. (1998). Teaching secondary English. Port Harcourt: Abicom Educational Services and Publications.

İon-English Dictionary (Kolokuma Dialect). (2002). Compiled by Ịọ̣n Language Development Programme Committee, Aba: National Institute for Nigerian languages.

Jenewari, C. E. W. (1980). Ijoid. In J. Bendor-Samuel (Ed.), The Niger Congo languages (pp. 105-118). Lanham, New York, and London: University Press of America.

Lightbown, P. M., \& Spada, N. (1993). How languages are learned. Oxford: Oxford University Press.

Ndimele, O.-M. (Ed.). (2001). Readings on language. Port Harcourt: M \& J Grand Orbit Communications Ltd..

Okaba, B. O. (2008). Use Ijaw language and culture or lose it. Being the text of a lecture delivered on the occasion of the 2008 Boro Day Celebration in the United Kingdom, London.

Prezi, G. T. (1988). Bouchard's culture, language and identity, 1998. A paper presented at a Post-Graduate Seminar in Sociolinguistics held at the University of Conakry, Guinea.

Prezi, G. T. (2004). Language, linguistics and publishing in Nigeria. An unpublished paper written for presentation at The Conference of the Linguistic Association of Nigeria held at the University of Port Harcourt, Choba, Port Harcourt.

Prezi, G. T. (2013). The numeral system of Ịzọn. In O.-M. Ndimele, \& E. S. L. Chan (Eds.), The numeral systems of Nigerian languages (pp. 245-257). Port Harcourt: LAN in Collaboration with M \& J Grand Orbit Communications Ltd..

Prezi, G. T. (2014). Nasalization of the initial consonant (d-) of the present perfect tense marker (-dẹ) after the main verb in İọn: A case study of the Tarakiri Dialect. US-China Foreign Language Journal, 12(1), 36-43.

Schachter, J. (1974). Language learning. Retrieved from interscience.wiley.com

Stern, H. H. (1983). Fundamental concepts of language teaching. Oxford: Oxford University.

Wardhaugh, R., \& Brown, H. D. (1976). A survey of applied linguistics. Ann Arbor: The University of Michigan Press.

Whitman, L. (1970). Contrastive analysis: Problems and procedures. Language Learning, 20, 191-197.

Williamson, K., \& Blench, R. (2000). "Niger-Congo". In B. Heine, \& D. Nurse (Eds.), African languages: An introduction (pp. 11-42). Cambridge: Cambridge University Press. 
Williamson, K. (1976). The rivers readers project in Nigeria. In A. Bamgbose (Ed.), Mother tongue education: The West African experience (pp. 135-153). London: Hodder and Stoughton; Paris: UNESCO Press.

Williamson, K. (1989a). Niger-Congo overview. In J. Bendor-Samuel (Ed.), The Niger-Congo languages (pp. 3-45). Lanham, New York, and London: American University Press.

Williamson, K. (1989b). Tone and accent in Ijọ. In H. V. D. Hulst, \& N. Smith (Eds.), Pitch accent systems (pp. 253-278). Dordrecht: Foris Publications.

Williamson, K. (2003). A common language for the ijaw ethnic nationality?. A lecture delivered to the Ijaw National Congress, Port Harcourt.

Williamson, K., \& Timitimi, A. O. (Eds.). (1983). A short İon-English dictionary (Delta series 3). Port Harcourt: University of Port Harcourt Press.

Williamson, K., Timitimi, A. O., Egberipou, O. A., Vianana, N. T. S., \& Odogu, C. T. (Eds.). (1990). A vocabulary of primary science and mathematics in Izon. Enugu: NERDC and First Dimension Publishing Co., Ltd.. 